\title{
PEREBUTAN RUANG PUBLIK PEDAGANG KAKI LIMA PADA MASA PANDEMI DI ALUN-ALUN JOMBANG
}

\author{
Widia Dwi Rahmawati ${ }^{1}$, Agus Mahcfud Fauzi ${ }^{2}$
}

\author{
Universitas Negeri Surabaya \\ widia.18073@mhs.unesa.ac.id
}

$\underline{\text { Received : } 27 \text { May } 2021 \text { | Reviewed: } 4 \text { June } 2021 \text { | Accepted: } 13 \text { July } 2021}$

\begin{abstract}
ABSTRAK
Mewabahnya Virus Covid-19 di Indonesia telah melemahkan berbagai sektor kehidupan di masyarakat, tak terkecuali sektor ekonomi. Berbagai kebijakan politik yang dikeluarkan pemerintah selama masa pandemi telah mengancam perekonomian masyarakat. Terutama masyarakat kalangan menengah bawah,seperti Pedagang Kaki Lima (PKL). PKL menjadi pihak yang sangat terdampak dari pemberlakuan kebijakan yang dilakukan pemerintah. Mulai dari kebijakan Pembatasan Sosial Berskala Besar (PSBB) hingga Pemberlakuan Pembatasan Kegiatan Masyarakat (PPKM). Kedua kebijakan tersebut sering kali memicu aksi perebutan ruang kota antara PKL dan aparat keamanan. Penelitian ini ditujukan untuk melihat politik ruang kota selama masa pandemi pada PKL di Alun-Alun Jombang. Metode yang digunakan dalam penelitian ini yaitu, pendekatan kualitatif. Dalam mendukung kajian ini, maka teori yang digunakan ialah Teori Strukturasi yang digagas oleh Anthony Giddens. Perspektif teori tersebut digunakan dalam melihat pola relasi antara struktur dan agen yang ada dalam politik ruang kota. Hasil dari penelitian ini menunjukkan bahwa perebutan ruang kota yang dilakukan oleh PKL menjadi wujud dari adanya hegemoni politik. Penguasaan tersebut membuat para PKL harus melakukan berbagai cara agar dapat bertahan hidup selama pandemi.
\end{abstract}

Kata Kunci: Ruang Publik, dan Pedagang Kaki Lima (PKL)

Korespondensi:

Universitas Negeri Surabaya

Jl. Lidah Wetan, Lidah Wetan, Kec. Lakarsantri, Kota

SBY, Jawa Timur 60213

E-mail:widia.18073@mhs.unesa.ac.id

JURNAL ILMIAH DINAMIKA SOSIAL 5 (1) 2021 | 17 


\begin{abstract}
The outbreak of the Covid-19 virus in Indonesia has weakened various sectors of life in the community, including the economic sector. Various political policies issued by the government during the pandemic have threatened the economy of the community. Especially the lower middle class, such as Street Vendors. Street Vendors became a party that is very affected by the implementation of policies carried out by the government. Starting from large-scale social restriction policies (PSBB) to the enforcement of restrictions on community activities (PPKM). Both policies often trigger urban space struggles between street vendors and security forces. This research is intended to look at the politics of urban space during the pandemic at pkl in Jombang Square. The method used in this study is qualitative approach. In support of this study, the theory used is the Theory of Structure initiated by Anthony Giddens. The theoretical perspective is used in looking at the pattern of relationships between structures and agents that exist in the politics of urban space. The results of this study show that the seizure of urban space conducted by pkl became a manifestation of the existence of political hegemony. The mastery makes the pkl have to do various ways in order to survive during the pandemic.
\end{abstract}

Keyword : Public Space, and Street Vendors

\title{
PENDAHULUAN
}

Munculnya pandemi Covid-19 atau yang lebih dikenal dengan virus Corona telah menjadi permasalahan global. Pandemi yang muncul pertama kali di Wuhan, Tiongkok ini telah menyebar ke berbagai penjuru dunia. Indonesia menjadi salah satu negara dengan tingkat peyebaran virus yang cukup tinggi. Berdasarkan Data Sebaran Covid-19 per Januari 2021, tercatat sebanyak 1.223.930 pasien terkonfirmasi positif, dan sekitar 158,498 kasus aktif, dan 33.367 pasien meninggal. Data tersebut masih terus mengalami peningkatan setiap harinya. Penyebaran virus yang cepat, membuat banyak negara melakukan pembatasan bahkan penutupan akses keluar masuk antar negara.

Kebijakan pembatasan sosial juga diterapkan oleh pemerintah di Indonesia. Terdapat dua kebijakan yang telah dijalankan selama masa Pandemi ini. Kebijakan pertama yang dijalankan oleh pemerintah yaitu, Pembatasan Sosial Berskala Besar (PSBB). Kebijakan ini telah diatur dalam PP Nomor 21 Tahun 2020. Secara rinci hal-hal yang berkaitan dengan PSBB dijabarkan dalam Peraturan Menteri Kesehatan (Permenkes) Republik Indonesia Nomor 9 Tahun 2020 tentang Pedoman PSBB. Pada penerapannya, PSBB memiliki beberapa kebijakan yang harus ditaati di lingkungan masyarakat. Mulai dari peliburan sekolah dan tempat kerja, yang dialihkan secara daring (dalam jaringan) atau online. Juga kegiatan lainnya seperti keagamaan, sosial budaya juga dibatasi. Tidak hanya itu, segala aktivitas yang dilakukan di tempat umum seperti penggunaan alat transportasi juga diperketat. Hal itu dilakukan sebagai upaya dalam memutus rantai penyebaran Covid-19.

Meskipun kebijakan PSBB ini telah diterapkan di berbagai wilayah di Indonesia. Akan tetapi, kebijakan tersebut dinilai kurang efektif dengan bertambahnya jumlah kasus yang dilaporkan di beberapa daerah. Berdasarkan kondisi tersebut, pemerintah mengeluarkan 
kebijakan baru berupa Penerapan Pembatasan Kegiatan Masyarakat (PPKM). Berbeda dengan PSBB, kebijakan ini ditujukan pada wilayah dengan karakteristik tertentu. Ciri-ciri daerah yang dimaksud meliputi empat hal. Pertama, angka kematian di daerah tersebut berada di atas ratarata nasional. Kedua, tingkat kesembuhan di daerah berada di bawah rata-rata nasional. Ketiga, angka kasus aktif daerah di atar rata-rata nasional. Terakir, keterisian rumah sakit untuk ICU dan ruang isolasi di atas 70 persen. Pemberlakuan kebijakan tersebut dikoordinasikan dengan kepala daerah yang bersangkutan.

Berdasarkan ciri tersebut, wilayah Jawa-Bali menjadi sasaran bagi pelaksanaan kebijakan PPKM. Jawa Timur menjadi provinsi dengan tingkat kasus Covid-19 yang tinggi. Kondisi tersebut menjadikan banyak daerah harus menerapkan kebijakan PPKM ini, tak terkecuali di Kabupaten Jombang. Penerapan kebijakan tersebut umumnya dilakukan di tempat-tempat umum atau ruang publik. Taman Kota atau yang lebih dikenal dengan AlunAlun menjadi salah satu ruang bagi pelaksanaan kebijakan tersebut. Bagi para Pedagang Kaki Lima (PKL), alun-alun bukan hanya sebagai ruang publik. Ruang publik sebagai lokasi berjualan PKL merupakan tempat strategis yang harus dipertahankan dari intervensi pihak lain (Handoyo, 2015).

PKL merupakan pelaku usaha di sektor informal yang turut merasakan dampak dari kebijakan PPKM. Pekerjaan ini dilakukan dengan cara menjual barang dagangan dengan harga yang terjangkau (Nasrulllo dan jamaludin, 2015). Lokasi yang digunakan oleh PKL dapat berpengaruh pada keberlangsungan kegiatan usaha (Ernawati, J., 1995). Proses penjualan yang dilakukan di tempat keramaian dapat mendukung pedagang untuk memperoleh target penjualan yang tinggi. Akan tetapi, adanya kebijakan pembatasan tersebut, membuat banyak PKL mengalami penurunan pendapatan hingga kehilangan pekerjaan. Hal ini disebabkan karena berbagai usaha politik yang ada di dalamnya. Ruang publik menjadi tempat bertemunya berbagai kepentingan. Sehingga, kontestasi kuasa untuk memenangkan pengaruh dan penerimaan publik atas suatu isu di dalam ruang publi tidak dapat terhindarkan (Arditama, 2016).

Penggusuran hingga penutupan paksa kios-kios PKL dilakukan dalam menjalankan kebijakan yang ada tersebut. Kondisi ini sering kali memicu aksi para PKL yang tidak terima dengan perlakuan aparat keamanan yang semena-mena. Penolakan terhadap kebijakan yng berlaku juga dikenal dengan istilah resistensi. Resistensi termasuk dalam tindakan rasional dan juga tindakan pengamanan untuk survive (Azhari, 2016). Tindakan tersebut tentunya tidak dapat dipisahkan dari campur tangan kekuasaan. Hal inilah yang menjadi fokus pada penelitian ini. Jika penelitian sebelumnya lebih memfokuskan pada pola resistensi yang dilakukan Pedagang Kaki Lima terhadap kebijakan yang ada. Maka dalam penelitian ini, lebih menitikberatkan pada politik ruang kota. Tujuan dari penelitian ini untuk melihat bagaimana struktur dan agen dalamfenomena Perebutan Ruang Publik bagi PKL di Alun-Alun Jombang

\section{KAJIAN TEORI}

Selama masa pandemi ini berbagai aktivitas masyarakat dibatasi, terutama kegiatan yang dilakukan di luar rumah. Langkah tersebut dijalankan sebagai salah satu upaya 
pemerintah dalam menekan angka penyebaran virus. Masyarakat dihimbau untuk tetap di rumah saja, termasuk belajar dan bekerja. Hal itu juga dilakukan oleh pemerintah dengan menetapkan pembatasan sosial, baik PSBB maupun PPKM Mikro. Kebijakan ini dinilai telah memberatkan sebagian masyarakat, khususnya para Pedagang Kaki Lima (PKL). Jam kerja yang terbatas, membuat banyak PKL mengalami penurunan pendapatan hingga kehilangan pekerjaan. Realitas tersebut secara tidak langsung memicu timbulnya konflik dalam masyarakat, khususnya antara PKL dan pemerintah. Secara sosiologis, hal ini dapat dikaji dengan menekankan pada aspek struktur dan agen.

\section{a. Ruang Publik}

Ruang publik menjadi bagian yang berkaitan dengan keberadaan kota. Menurut Lefebvre (1991), ruang kota adalah ruang publik yang memproduksi ruang sosial dengan berbagai aktivitas masyarakat di dalamnya. Dalam memahami konsep ruang publik, perlu memperhatikan beberapa aspek (Purwanto, 2008). Pertama, ruang publik merupakan tempat interaksi antar individu maupun komunitas untuk berbagi tujuan. Kedua, aspek keterjangkauan atau aksesibilitas. Ruang publik menjadi tempat yang dapat dimanfaatkan oleh masyarakat yang membutuhkan. Ketiga, universalitas bahwa penyediaan ruang publik semestinya dapat mempertimbangkan berbagai kelas dan status kebutuhan masyarakat. Ruang publik menjadi wahana berkumpul masyarakat, tanpa perbedaan etnis, gender, dan umur. Keempat, ruang publik akan bermakna jika terdapat kepublikan atau publicness.

Berdasarkan lokasinya, ruang publik dibedakan menjadi dua jenis yaitu out door public space dan indoor public space (Huat, 1979). Out door public space merujuk pada area yang berada di luar ruangan. Misalnya lapangan, taman terbuka, jalan, dan lain sebagainya. Sedangkan, indoor public space merupakan ruang publik yang berada di dalam bangunan, seperti pusat perbelanjaan maupun gedung pertemuan. Kedua lokasi ruang publik ini samasama memegang peranan penting dalam menyediakan sarana dan prasarana bagi masyarakat. Oleh karena itu, keberadaan ruang publik saat ini saling terikat dengan berbagai aktivitas sekaligus interaksi sosial.

Ruang publik yang berada di pusat kota menjadi kawasan yang paling menonjol. Kondisi tersebut didukung oleh berbagai aktivitas yang ada di dalamnya, seperti perdagangan, hiburan, budaya, hingga pemerintahan. Keberadaan sarana dan prasarana juga turut 
mendukung aktivitas yang berkembang dalam ruang publik tersebut. Dengan demikian, keberadaan ruang publik di wilayah perkotaan menjadi penting bagi masyarakat, terutama dalam lingkup kegunaannya.

Ruang kota ini dapat dijangkau dengan mudah oleh khalayak umum, baik secara visual maupun fisik. Aspek visual didasarkan pada kawasan sebagai hasil interaksi antara masyarakat dengan lingkungan kota. Aspek ini berkaitan erat dengan perspeksi masyarakat mengenai karakter ruang dengan kondisi alami (natural) dan budaya (cultural).Sedangkan, aspek fisik berkaitan dengan pengelolaan tata ruang kota. Aspek ini terwujud dari beragamnya ruang publik yang tercipta di kawasan perkotaan.

\section{b. Pedagang Kaki Lima}

Pedagang kaki lima (PKL) merupakan salah satu jenis pekerjaan yang banyak dijalankan oleh masyarakat perkotaan. Istilah Pedagang kaki lima lebih diarahkan pada 3 kaki gerobak dan 2 kaki pedagang, sehingga disebut Pedagang Kaki Lima. Secara definisi PKL ialah pedagang yang menggunakan bahu jalan atau trotoar untuk berdagang. Menurut Permadi (2007), PKL merupakan pedagang yang menggelar dagangannya di pinggir jalan (trotoar) dengan lebar lima kaki (five feet).

Pekerjaan ini termasuk dalam jenis pekerjaan yang bergerak di sektor informal (Ismanidar, 2016:147). Pekerjaan ini dilakukan dengan menjual barang dan jasa yang menggunakan ruang publik sebagai lokasi untuk berdagang. Timbulnya kegiatan tersebut disebabkan oleh interaksi yang terjadi antara masyarakat sebagai pengguna ruang publik. Hal ini menjadi salah satu bentuk prinsip demand (permintaan) dan supplay (penawaran). Dengan demikian, terjadi penggunaan ruang publik (public space) sebagai kawasan sektor informal (informal sector).

Keberadaan PKL di lingkungan perkotaan memberikan dampak positif dan negatif bagi perekonomian masyarakat sekitar. Keberadaan PKL di sektor informal dianggap sebagai sabuk penyelamat yang mampu menampung kelebihan tenaga kerja dari sektor formal.PKL memberikan peluang peningkatan pendapatan daerah dan sebagai upaya untuk mengurangi pengangguran. Hal ini disebabkan karena untuk menjadi PKL tidak dibutuhkan skill yang lebih dan hanya perlu modal yang minim. 
Selain itu, PKL dalam perkotaan menimbulkan masalah terutama dalam segi keindahan kota. Keberadaan PKL di kawasan perkotaan sering kali muncul secara spontan atau tanpa perencanaan. Sehingga, penyebarannya tidak terintegrasi dengan perancangan kota. Banyak sekali PKL yang menggunakan ruang publik sehingga menimbulkan kesan kumuh dalam perkotaan. Pengaturan terhadap keberadaan PKL baru dilakukan ketika pengguna ruang publik terganggu atau adanya kepentingan tertentu. Dengan demikian, posisi PKL sebagai sektor informal di perkotaan menimbulkan dikotomis di masyarakat. Di satu sisi menjadi sektor yang dibutuhkan oleh masyarakat, dan di sisi lain menimbulkan berbagai permasalahan.

\section{METODE PENELITIAN}

Pendekatan yang dijadikan sebagai landasan dalam kajian ini yaitu, jenis penelitian kualitatif. Metode ini lebih menekankan pada kajian yang mendalam terhadap suatu fenomena atau permasalahan yang akan diteliti. Sedangkan, dalam proses memahami fenomena politik dalam kajian ini akan digunakan pendekatan institusionalisme. Pendekatan tersebut memfokuskan pada lembaga negara sebagai kajian utama. Hal-hal yang dilihat dari metode tersebut yaitu, gambaran umum lembaga atau organisasi, tugas pokok dan fungsi, serta peran lembaga dan cara lembaga berinteraksi.

Penelitian ini akan dilakukan di Kabupaten Jombang, tepatnya di Alun-Alun Kota yang berada di Jl. Diponegoro No. 1-3, Kaliwungu. Pemilihan tempat tersebut didasarkan pada keberadaan Sentra Pedagang Kaki Lima di sekitar Alun-Alun.Pada masa pandemi ini, keberadaan PKL tetap dapat ditemukan di sekitar Alun-alun. Meskipun, saat ini telah terdapat kebijakan pembatasan sosial, berupa PSBB dan PPKM. Kebijakan yang mewajibkan masyarakat untuk menghindari kerumunan, tentu berdampak bagi kondisi PKL saat ini. Selain membuat pendapatan PKL menurun, kebijakan tersebut telah menunjukkan adanya politik ruang yang dilakukan oleh pemegang kekuasaan terhadap PKL.

Waktu penelitian dilakukan pada bulan Januari-Februari 2021 sesuai dengan kebutuhan data di lapangan. Pemilihan waktu tersebut ditujukan untuk melihat dampak yang dihasilkan dari pemberlakuan kebijakan PSBB dan PPKM bagi PKL di Alun-Alun Kota. Subjek yang diambil dalam penelitian ini yaitu para PKL yang ada di Alun-Alun Kabupaten Jombang. Penarikan sampel penelitian menggunakan teknik random sampling atau pengambilan sampel secara acak kepada PKL. Teknik pengumpulan data dilakukan secara langung dan tidak langsung. Pengumpulan secara langsung, dilakukan melalui proses 
observasi atau pengamatan, wawancara, dan dokumentasi. Jenis data yang diperoleh yaitu data primer dan data sekunder. Data Primer berupa hasil wawancara langsung kepada informan penelitian. Sedangkan, data sekunder diperoleh dari kajian pustaka maupun dokumen-dokumen terkait.

Data yang telah diperoleh di lapangan, selanjutnya akan di analisis melalui tiga tahap. Tahap yang pertama yaitu reduksi data, di mana data yang telah diperoleh akan dirangkum, dipilih, dan diseleksi sesuai dengan kebutuhan penelitian. Kemudian, tahap berikutnya yaitu penyajian data. Data yang telah dihasilkan dapat disajikan melalui analisis narasi yang dapat mengungkapkan suatu temuan. Selanjutnya, pada tahap terakhir yaitu penarikan kesimpulan. Pada tahap ini, berupa paparan temuan baru atau hasil yang belum pernah ada sebelumnya.

\section{PEMBAHASAN}

\section{Dampak Pembatasan Sosial bagi Pedagang Kaki Lima}

Indonesia menjadi negara dengan tingkat penyebaran virus Cozid-19 yang cukup tinggi. Secara global, menurut data sebaran Covid-19 yang dirilis oleh Coronavirus Research Center (2020), Indonesia menduduki peringkat ke-19 dari 189 negara dengan total kasus sebanyak 373.109. Tingginya kasus paparan Covid-19 di Indonesia, membutuhkan penanganan yang tepat dalam menekan angka penyebaran. Dalam upaya penanganan kasus tersebut, pemerintah mengeluarkan beberapa kebijakan. Salah satunya yaitu Pembatasan Sosial Berskala Besar (PSBB) dan Penerapan Pembatasan Kegiatan Masyarakat (PPKM).

PSBB merupakan kebijakan yang dibuat oleh Kementrian Kesehatan (Kemenkes) sebagai upaya percepatan penanganan Covid-19. Oleh Kemenko PMK (2020), regulasi tersebut termuat dalam Peraturan Menteri Kesehatan Nomor 9 Tahun 2020. Adanya kebijakan ini membuat beberapa aktivitas di masyarakat dibatasi. Mulai dari kegiatan pembelajaran di sekolah yang dialihkan pada sistem daring (online), hingga bekerja dari rumah (work from home/WFH). Selain itu, kegiatan ini juga membatasi aktivitas keagamaan masyarakat dengan ditutupnya tempat-tempat ibadah. Pembatasan kegiatan juga diberlakukan pada kegiatan sosial budaya, dan juga penggunaan tempat/fasilitas umum lainnya.

Kebijakan ini diperketat dengan dibentuknya Satuan Tugas (Satgas) Penanganan Covid-19. Pembentukan Satgas ini ditujukan untuk mengajak seluruh masyarakat menjadi 
garda terdepan dengan menerapkan 3 hal utama yaitu menjaga iman, aman dan imun (Satgas, 2020). Iman berkaitan dengan menjalankan ibadah sesuai agama dan kepercayaan masingmasing. Sedangkan Aman sebagai kepatuhan totalitas terhadap protokol kesehatan pencegahan Covid-19 melalui gerakan 3M (Memakai masker, Menjaga Jarak dan Menghindari kerumunan, serta Mencuci tangan menggunakan sabun). Kemudian Imun harus dijaga dengan cara mengonsumsi makanan bergizi, menjaga kesehatan mental, rajin berolahraga, dan istirahat yang cukup. Ketiga hal tersebut perlu dilakukan oleh masyarakat dalam kehidupan sehari-hari, terutama gerakan $3 \mathrm{M}$.

Pada penerapannya kebijakan ini berdampak pada segala aspek kehidupan di masyarakat, terutama perekonomian. Hal ini disebabkan karena adanya pembatasan jam dan/atau kapasitas operasional sektor usaha selama PSBB berlangsung. Aturan ini juga berlaku bagi penggerak usaha di sektor informal, seperti Pedagang Kaki Lima (PKL). Para PKL dihimbau untuk patuh terhadap kebijakan yang telah ditetapkan. Kegiatan ini dipantau oleh aparat keamanan setempat yang merupakan petugas gabungan dari Satpol PP, Suku Dinas Perhubungan, dan Polisi. Bagi para pelanggar, akan memperoleh sanksi yang tegas dari aparat keamanan setempat. Mulai dari penyitaan barang hingga penutupan lokasi berjualan secara paksa. Tindakan ini juga dialami oleh beberapa PKL di kawasan Alun-Alun Jombang yang memilih tetap berjualan di masa pandemi.

Meskipun kebijakan pembatasan telah diterapkan, tetapi angka penyebaran Covid-19 masih cukup signifikan. Jombang menjadi salah satu kabupaten di Jawa Timur yang masuk dalam zona merah penyebaran Covid-19. Secara nasional, wilayah Jawa dan Bali masih menunjukkan angka penyebaran yang tinggi. Kondisi ini membuat pemerintah merumuskan kebijakan baru berupa Penerapan Pembatasan Kegiatan Masyarakat (PPKM). PPKM ini sebagai pengganti PSBB yang diberlakukan sejak 11-25 Januari 2021. Kebijakan tersebut berlaku di wilayah DKI Jakarta dan 23 kabupaten/kota di enam provinsi yang masuk wilayah berisiko tinggi penyebaran Covid-19. Kawasan Jombang, menjadi salah satu wilayah yang terdampak dari adanya kebijakan PPKM ini.

Berbeda dengan PSBB, PPKM memiliki lingkup yang lebih kecil atau berskala mikro. Penerapan kebijakan ini dilakukan di masing-masing daerah yang telah ditentukan oleh pemerintah daerah. Kebijakan yang diberlakukan dalam PPKM Mikro ini antara lain yaitu, 
membatasi tempat kerja dengan WFH 75 persen dengan tetap menerapkan protokol kesehatan yang berlaku. Kemudian, kegiatan belajar mengajar tetap dilakukan secara daring (online). Selanjutnya, kegiatan di pusat perbelanjaan diizinkan hingga pukul 19.00. Sedangkan, tempat makan dan minum di tempat maksimal hanya 25 persen dari kapasitas ruang yang disediakan. Akan tetapi, proses pemesanan makanan melalui take away atau delivery tetap diperbolehkan. Kegiatan di tempat ibadah juga mulai dibuka dengan kapasitas sebesar 50 persen serta wajib mematuhi protokol kesehatan. Kemudian, untuk penggunaan transportasi umum menyesuaikan kapasitas dan jam operasional. Namun, untuk kegiatan sosial budaya dihentikan sementara.

Kebijakan PPKM ini dinilai mampu menekan penyebaran virus Covid-19, sehingga pemerintah memperpanjang dan memberlakukan PPKM Mikro. Kebijakan ini sebagai bentuk pengendalian pada level terkecil, yaitu Rukun Tetangga (RT). PPKM Mikro mulai diterapkan pada 9-22 Februari 2021. Pada pelaksanaannya, kebijakan ini didukung dengan adanya posko jaga desa/kelurahan. Kegiatan tersebut bertujuan untuk melakukan penanganan, pencegahan, pembinaan, dan pendukung. PPKM Mikro dilakukan dengan memaksimalkan 3T, yaitu testing (tes), tracking (pelacakan), dan treatment (pengobatan) (Setkab, 2021). Kedua kebijakan di atas memiliki pengaruh yang cukup signifikan bagi aktivitas di masyarakat, tak terkecuali bagi PKL.

Ruang publik menjadi tempat berlangsungnya aktivitas serta interaksi masyarakat,sehingga intensitas penggunaannya cukup tinggi. Kondisi ini menjadi pusat pengawasan bagi aparat keamanan dalam menjalankan berbagai kebijakan yang berlaku selama masa pandemi. Ketatnya peraturan yang ada, membuat PKL harus menyesuaikan dengan perubahan yang ada. PKL sebagai sektor informal yang menempati kawasan perkotaan, khususnya di ruang-ruang publik memberi pengaruh yang besar terhadap pengawasan kebijakan tersebut. Beberapa hal yang dilakukan oleh para PKL antara lain, yaitu:

\section{a. Modifikasi Kios Dagang}

Perubahan pola berdagang menjadi salah satu bentuk adaptasi PKL dengan adanya kebijakan PSBB. Beberapa PKL melakukan modifikasi pada sarana yang digunakan untuk berjualan. Sebagian besar PKL yang ada di Alun-Alun Jombang sebelumnya menggunakan kios dagang yang digelar di pinggir jalan. Akan tetapi, semenjak pemberlakuan PSBB kawasan Alun-Alun Jombang menjadi area razia aparat keamanan. Kegiatan razia atau operasi gabungan ini 
biasanya dilakukan sebanyak 4 hingga 5 kali dalam sehari. Akibatnya, para PKL yang melanggar perturan akan memperoleh sanksi baik berupa denda uang maupun penyitaan barang dagangan. Sebagai upaya menghindari razia tersebut, beberapa PKL mengubah kios atau gerobak bongkar pasang menjadi gerobak instan. Gerobak ini dimodifikasi dengan digabungkan pada kendaraan bermotor, sehingga mudah dibawah berpindah tempat. Perubahan ini dilakukan sebagai antisipasi apabila terdapat kegiatan penertiban kawasan AlunAlun Jombang.

b. Penyesuaian Jam Operasional

Sesuai dengan kebijakan yang diberlakukan dalam PSBB maupun PPKM Mikro, maka sistem dagang juga memperhatikan aturan yang ada. Para PKL melakukan kegiatan berjualan sesuai dengan jam yang telah ditentukan. Penyesuaian jam operasional ini lebih menekankan pada aktivitas berjualan di malam hari. Jika pada kebijakan PSBB sebelumnya, aktivitas masyarakat saat malam hari dibatasi sampai pukul 19.00 WIB. Maka, pada penerapan PPKM dan PPKM Mikro jam malam yang diberikan menjadi lebih longgar. Para PKL yang memiliki jam kerja malam, diberikan waktu buka maksimal sampai pukul 22.00 WIB. Aktivitas makan dan minum di tempat juga dibatasi hingga 25 persen dari tempat yang tersedia. Berbeda dengan kegiatan PKL yang dilakukan pada pagi, siang, dan sore hari, tidak terdapat batasan waktu operasional. Akan tetapi, pembukaan kegiatan usaha PKL harus tetap mematuhi protokol kesehatan yang telah ditentukan. Seperti, menyediakan tempat cuci tangan, menjaga jarak, dan menggunakan masker.

c. Mobilisasi Tempat Berjualan

Alun-Alun yang terletak di pusat kota, menjadi kawasan yang tidak lepas dari pantauan aparat keamanan selama pemberlakuan PSBB maupun PPKM. Kondisi ini semakin mempersulit ruang gerak PKL yang biasanya berjualan di sekitar kawasan tersebut. Akibatnya, para PKL melakukan mobilisasi ke beberapa daerah untuk mengurangi resiko razia yang dilakukan oleh aparat keamanan. Selain menghindari kegiatan razia, perpindahan ini dilakukan untuk menerapkan protokol kesehatan yakni, menjaga jarak antar kios dagang. Lokasi yang menjadi area berjualan PKL Alun-Alun Jombang saat ini yaitu di sepanjang Jalan Pattimura, Jalan 
Kusuma Bangsa, dan Jalan dr. Sutomo. Sepanjang jalan tersebut, para PKL menggelar barang dagangan dengan menerapkan jaga jarak antar satu kios dengan kios lainnya. Lokasi dagang ini menjadi lebih sempit karena terletak di pinggir jalan, sehingga kegiatan makan dan minum menjadi minim ditemukan. Namun, keberadaan PKL di sepanjang jalan tersebut membuat kondisi jalan menjadi ramai bahkan menimbulkan kemacetan.

\section{d. Peralihan Sistem Dagang}

Peralihan pekerjaan menjadi salah satu langkah yang dilakukan oleh para PKL agar tetap dapat memenuhi kebutuhan keluarga. Jenis pekerjaan yang biasanya dilakukan secara langsung melalui gerobak atau kios, kini dialihkan melalui sistem jual beli online. Pemnafaatan platform media sosial menjadi alternatif baru kegiatan berdagang saat ini. Selain, dapat menjangkau konsumen yang lebih luas, aktivitas jualan online dapat meminimalisir kerumunan dan mencegah terjadinya penularan virus secara langsung. Peralihan pekerjaan ini dilakukan,sebab para PKL dilarang berjualan di sekitar Alun-alun. Seperti yang dilakukan oleh salah satu pedagang molen yang melakukan peralihan pekerjaan menjadi penjual sabuk online. Meskipun, penghasilan yang diperoleh tidak sebanding dengan pendapatan sebagai PKL. Namun, setidaknya dapat mencukupi kebutuhan sehari-hari daripada menganggur.

Berdasarkan realitas diatas, menjadi cukup menarik untuk melihat adanya politik ruang yang terjadi pada PKL di Alun-Alun Jombang. Wilayah perkotaan tidak hanya menjadi ruang terjadinya berbagai aktivitas sosial, ekonomi, budaya dan sebagainya. akan tetapi, menjadi ruang politik yang mempertemukan berbagai kepentingan-kepentingan di dalamnya. Kebijakan pembatasan sosial yang ketat telah menempatkan para PKL dalam posisi tersubordinasi. Penguasaan terhadap ruang kota membuat banyak PKL harus menetapkan berbagai strategi agar tetap memperoleh penghasilan untuk memenuhi berbagai kebutuhan.

\section{Relasi Agen dan Struktur dalam Politik Ruang Kota}

Pada aksi perebutan ruang kota yang terjadi pada Pedagang Kaki Lima di Alun-Alun Jombang terjadi hubungan antara struktur dan agen. Menurut Giddens (1984), terdapat dualitas dan hubungan dialektis antara agensi dan struktur. Dalam teori Strukturasi menekankan bahwa, semua tindakan sosial akan melibatkan struktur, dan semua struktur melibatkan tindakan sosial. Keduanya terjalin erat dalam aktivitas atau praktik yang terus menerus dijalankan oleh 
manusia. Agen dalam hal ini merujuk pada individu yang bertindak secara independent dalam membuat pilihannya sendiri. Pada kajian ini, posisi agen dipegang oleh para Pedagang Kaki Lima (PKL) yang ada di Alun-Alun Jombang. Sedangkan struktur lebih mengarah pada proses penataan yang memiliki pola dan dilakukan berulang yang dapat mempengaruhi atau membatasi pilihan serta kesempatan orang lain. Struktur ini merujuk pada seperangkat aturan yang dibuat oleh pemerintah, seperti kebijakan PSBB dan PPKM-Mikro. Secara tidak langsung, kedua kebijakan tersebut membatasi ruang gerak bagi PKL.

Mekanisme berdagang yang dilakukan oleh para PKL di Alun-Alun Jombang di masa pandemi merupakan bentuk aktivitas yang menjadi bagian dari agensi. Kegiatan tersebut menjadi berhubungan dengan struktur yang ada, akibat adanya aturan atau kekuasaan yang berperan. Pemberlakuan pembatasan melalui kebijakan PSBB maupun PPKM membuat para PKL melakukan tindakan sosial yang beragam. Mulai dari modifikasi cara berdagang hingga alih pekerjaan. Berbagai aktivitas tersebut tidak dihasilkan dari kesadaran akan konstruksi sosial atas realitas, pun tidak pula dihasilkan oleh struktur sosial.

Jika didasarkan pada kondisi saat ini, keberadaan pandemi telah melumpuhkan berbagai sektor, terutama perekonomian. Adanya kebijakan pembatasan sosial, seperti PSBB dan PPKM membuat banyak pekerja di sektor formal maupun informal terbatasi. Misalnya, aksi PHK yang dilakukan secara besar-besaran telah menimbulkan banyaknya pengangguran. Bagi PKL, kondisi pandemi juga telah mengancam ekonomi keluarga. Namun, pada kenyataannya para PKL tetap menjalankan usaha melalui berbagai cara. Ketika individu mengekspresikan dirinya sebagai aktor, individu tersebut akan melakukan praktik, dan melalui praktik inilah kesadaran dan struktur dihasilkan (Ritzer, 2016). Kesadaran dalam hal ini disebut sebagai suatu refleksivitas.

Melalui pemahaman kondisi keterbatasan saat ini, para PKL melakukan beragam cara agar tetap dapat berjualan dan memperoleh pendapatan. Aksi reflektif ini menjadi bagian yang tidak terlepas dari adanya struktur. Struktur menjadi sesuatu yang mempengaruhi atau membatasi pilihan dan kesempatan seseorang, dalam hal ini yaitu aturan. Pembatasan jam malam merupakan salah satu bentuk aturan yang membatasi ruang gerak bagi para PKL. Akibatnya, tidak sedikit para PKL yang memberontak ketika ditertibkan oleh aparat keamanan yang bertugas. Tindakan tersebut menjadi bagian dari kesadaran yang terbentuk atas realitas 
yang didapat oleh agen. Ketika menjadi reflektif, aktor tidak hanya sadar diri, tetapi juga terlibat dalam pengamatan atas aliran aktivitas dan kondisi sosial yang tengah berlangsung. Secara umum, teori strukturasi ini lebih memperhatikan proses dialektis tempat dihasilkannnya praktik, struktur, dan kesadaran.

Pada ranah kesadaran, Giddens membagi ke dalam dua jenis yaitu, kesadaran diskursif dan kesadaran praktis (Priyono, 2016). Kesadaran diskursif mengantarkan aktor pada kemampuan menjabarkan tindakan melalui kata-kata (bahasa). Kesadaran diskursif ini dapat diamati dalam berbagai aksi pemberontakan PKL akibat penertiban yang dilakukan oleh aparat keamanan. Sedangkan kesadaran praktis, melibatkan tindakan yang diterima begitu saja oleh aktor, tanpa mampu mengekspresikannya melalui kata-kata (bahasa). Tipe kesadaran kedua inilah yang menjadi kajian penting dalam teori strukturasi. Dengan memfokuskan pada kesadaran praktis inilah terjadi transisi dari agen menuju agensi. Agensi terdiri dari peristiwa yang didalamnya individu bertanggung jawab atas peristiwa tersebut. Kesadaran praktis ini ditunjukkan melalui beragam tindakan yang dilakukan oleh PKL agar tetap memperoleh penghasilan di tengah keterbatasan. Tindakan tersebut berupa modifikasi kios dagang, penyesuaian jam operasional, mobilisasi tempat berjualan, dan alih pekerjaan.

Gagasan ini menjadi penting untuk membawa agensi ke ranah sistem sosial. Agensi terpisah dari kehendak, sebab tindakan yang dilakukan secara sengaja sering kali membawa konsekuensi yang tidak dikehendaki. Jika para PKL memilih menutup kios dagang akibat adanya kebijakan PSBB dan PPKM. Maka, para PKL tentu tidak akan memperoleh pengahasilan sama sekali. Oleh karena itu, agen harus memiliki kemampuan menciptakan perbedaan di dunia sosial. Melalui berbagai tindakan atau mekanisme dagang para PKL tetap dapat memperoleh penghasilan. Tegasnya, agen tidak mungkin ada tanpa kekuasaan; seorang aktor tidak lagi menjadi agen jika kehilangan kapasitas untuk menciptakan perbedaan. Secara logis, kekuasaan mendahului subjektivitas sebab tindakan melibatkan kekuasaan atau kemampuan mengubah situasi. Mekanisme dagang di masa pandemi yang dilakukan oleh para PKL menjadi bagian dari kekuasaan para pedangan. Kekuasaan tersebut menjadi bagian dari aparat keamanan, bila para pedagang tidak memiliki kemampuan dalam mengubah situasi yang ada. Misalnya dengan memilih tetap berjualan pada jam normal, sehingga sering kali ditertibkan oleh petugas. Dengan demikian, teori strukturasi Giddens menempatkan kekuasaan 
pada aktor dan tindakan yang bertolak belakang dengan teori yang cenderung mengabaikan orientasi tersebut.

Konsep inti dari teori ini terletak pada gagasan mengenai struktur, sistem, dan dualitas struktur. Struktur diartikan sebagai segala sesuatu yang menstrukturkan, juga segala sesuatu yang memungkinkan adanya praktik sosial. Keberadaan struktur dalam masyarakat tidak dapat dipisahkan begitu saja. Sebagian besar struktur telah mempengaruhi kondisi maupun aktivitas di masyarakat. Kebijakan pembatasan sosial seperti PSBB dan PPKM Mikro merupakan salah satu struktur baru yang lahir di masyarakat pada masa pandemi. Keberadaan struktur tersebut telah mengubah berbagai sektor kehidupan yang ada. Misalnya dalam pendidikan, aktivitas sosial, buda, keagmaan, juga ekonomi. Kebijakan ini telah membentuk beragam praktik sosial di masyarakat. Misalnya dalam sektor ekonomi, para PKL di Alun-Alun Jombang melakukan berbagai upaya pembaharuan dalam berdagang. Berdasarkan hal tersebut, maka struktur dapat terbentuk karena adanya aturan dan sumber daya. Keduanya mewujudkan dirinya sendiri pada level makro sistem sosial dan level mikro kesadaran manusia. Struktur tidak dengan sendirinya berada dalam ruang dan waktu, namun termanifestasikan dalam sistem sosial berupa praktik yang direproduksi.

\section{KESIMPULAN}

Wilayah perkotaan menjadi ruang yang merefleksikan masyarakat secara kompleks. Selain memiliki berbagai akses yang mudah, kota menjadi arena pertarungan politik bagi beberapa kelompok. Hal ini ditunjukkan pada perebutan ruang kota yang dilakukan oleh para Pedagang Kaki Lima (PKL) yang ada di Alun-Alun Jombang. Pada masa pandemi, para PKL mengalami berbagai keterbatasan. Kondisi tersebut disebabkan oleh adanya pembatasan sosial melalui kebijakan PSBB dan PPKM Mikro. Realitas tersebut menunjukkan adanya hubungan dialektis antara agen dan struktur yang ada di masyarakat.

Posisi agen yang dipegang oleh para PKL, terbentuk atasdasar kesadaran reflektvitas. Kesadaran tersebut menjadikan para PKL tetap dapat melakukan aktivitas berdagang selama masa pembatasan sosial. Berbagai aktivitas tersebut seperti melakukan modifikasi pada kios dagang, menyesuaikan jam operasional sesuai dengan aturan yang berlaku, melakukan mobilisasi tempat berjualan, hingga melakukan alih profesi. Praktik sosial tersebut dilakukan sebagai bagian dari kesadaran para PKL sebagai aktor. Praktik ini, tentu tidak terlepas dari 
orientasi otoritas struktur. Struktur berperan dalam proses penataan pola secara berulang yang dapat mempengaruhi atau mebatasi kesempatan dan pilihan seseorang.

\section{DAFTAR PUSTAKA}

Arditama, E. (2016). Mengkaji Ruang Publik dari Perspektif Kuasa: Fenomena Kemenangan Aktor Hegemonik Melalui Dominasi Budaya. Politik Indonesia: Indonesian Political Science Review, 1(1), 69. https://doi.org/10.15294/jpi.v1i1.9181

Azhari, M. B. (2016). Resistensi Pedagang Kaki Lima Terhadap Kebijakan Pemerintah Kota Semarang. Universitas Negeri Semarang.

Coronavirus Resource Center. (2020). COVID-19 Dashboard by the Center for Systems Science and Engineering (CSSE) at Johns Hopkins University \& Medicine. Retrieved October 22, 2020, from https://coronavirus.jhu.edu/map.html

Ernawati, J., T. W. S. dan H. S. (1995). Preferensi Pedagang Kaki Lima Terhadap Eaktorfaktor Lokasi Tempat Mangkal dalam Melakukan Aktifitas Perdagangan di Kota Malang.

Giddens, A. (1984). The Constitution Of The Theory of Structuration. Polity Press.

Handoyo, E. (2015). Makna Ruang Publik Bagi Pedagang Kaki Lima : Studi tentang Resistensi terhadap Penggusuran. Prosiding Seminar Nasional Multi Disiplin Ilmu \& Call For Papers UNISBAK (SENDI_UI), (1), 978-979.

Huat, C.B. 1992. Public Space, Desaign, and Management. Singapore University Press.

Ismanidar. 2016. "Persepsi Masyarakat Terhadap Pedagang Kaki Lima di Kota Banda Aceh".Jurnal Ilmiah Mahasiswa Pendidikan Kewarganegaraan Unsyiah. Universitas Syiah Kuala.

Lefebvre, H., 1991. The Production Space. Blackwell Publishing

KEMENKO PMK. (2020). Pembatasan Sosial Berskala Besar. Retrieved February 21, 2021, from Kementerian Koordinator Bidang Pembangunan Manusia dan Kebudayaan Republik Indonesia website: https://www.kemenkopmk.go.id/pembatasan-sosialberskala-besar

Nasrulllo, Dr. Adon jamaludin, M. A. (2015). Sosiologi Perkotaan (Memahami Masyarakat KOta dan Problematikanya) (ke 2; Tim Redaksi Pustaka Setia, Ed.). Bandung: PUSTAKA SETIA. 
Permadi, Gilang. 2007. Pedagang Kaki Lima: Riwayatmu Dulu, Nasibmu Kini. Jakarta: Yudhistira.

Priyono, B. H. (2016). Anthony Giddens Suatu Pengantar. Jakarta: KPG (Kepustakaan Populer Gramedia).

Purwanto, Edi. 2008. Relasi Rancangan Kota dan Anarki Warga. Proseding Seminar Nasioanl "Sticks and Carrots". Halaman II.209-II.219.

Ritzer, G., \& Godman, D. J. (2016). Teori Sosiologi. Yogyakarta: Kreasi Wacana.

Satuan Tugas Penanganan Covid-19. (2020). Pedoman perubahan perilaku.

Sekretariat Kabinet Republik Indonesia. (2021). Tekan Kasus Covid-19, Pemerintah Terapkan PPKM Berbasis Mikro Mulai 9 Februari. (Online). https://setkab.go.id/tekan-kasuscovid-19-pemerintah-terapkan-ppkm-berbasis-mikro-mulai-9-februari. 